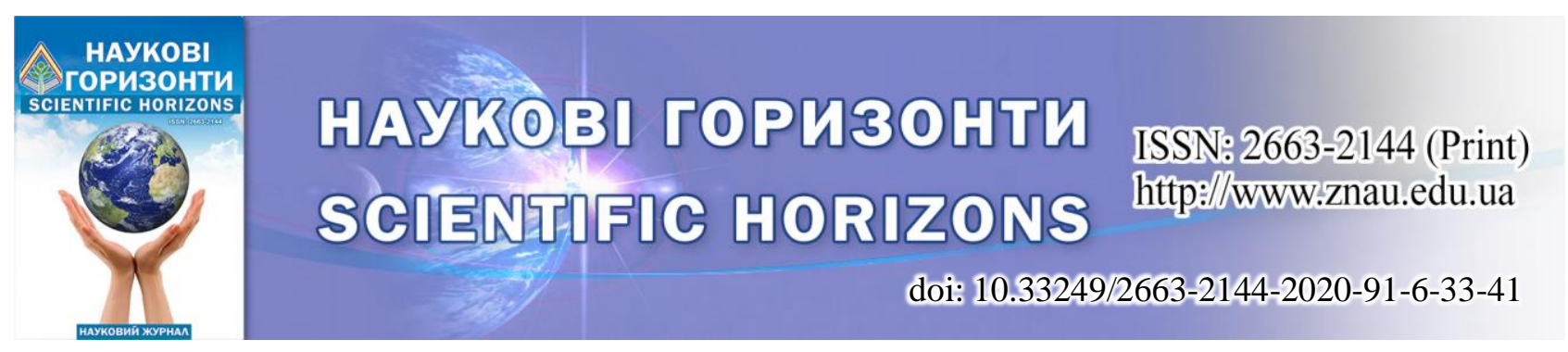

UDC 631.3: 332.1

\title{
AGRI-INDUSTRIAL PARKS AS A VECTOR OF SOCIOECONOMIC DEVELOPMENT OF TERRITORIAL COMMUNITIES: STATISTICAL ASPECT
}

Article info
Received
24.04 .2020
Accepted
24.06 .2020

${ }^{1}$ Zhytomyr
National
Agroecological
University
7, Staryi Blvd,
Zhytomyr,
10008, Ukraine
2 Jagiellonian
University
24, Golebia,
Krakow,
31-007, Poland

E-mail: morozyy@ukr.net; schugaevskaya@ ukr.net; natalia.chugaievska @gmail.com

\author{
Y. Moroz ${ }^{1}$, S. Chugaievska ${ }^{1}$, N. Chugaievska ${ }^{2}$
}

Moroz, Y., Chugaievska, S., Chugaievska, N. (2020). Agri-industrial parks as a vector of socioeconomic development of territorial communities: statistical aspect. Scientific Horizons, 06 (91), 33-41. doi: 10.33249/2663-2144-2020-91-6-33-41.

Modern development of territorial communities requires the creation of new modern approaches and the necessary conditions for their socioeconomic development on the basis of innovation and investment. The decentralization reform is aimed at creating additional financial resources in the regions, stimulating the management of local community development, launching new economic formations which are based on the transfer of power to the local government. The purpose of the study is to substantiate the theoretical and practical positions on the aim at the formation of agriindustrial parks in the territories of the United Territorial Communities (UTC) of Ukraine, which will promote the development of rural areas on an innovation and investment basis.

The key tasks include: research of regional transformations of decentralization reform; analysis of factors of living standards and labor migration of the rural population; development of a human-centered model of development of territorial communities; analysis of ways to improve the social and financial situation in the community on the base of the results of a survey of local community deputies; determining the stages of implementation of the strategy of creating agri-industrial parks. The study is based on the following methods: monographic, graphic, abstractlogical, methods of analysis and synthesis. The authors propose mechanisms for launching a new type of entities formations in the territories of UTC of Ukraine - agriindustrial parks, which in the long run will promote the development of rural areas on an innovation and investment basis. The study of the field of common interests of stakeholders in this process confirmed the need for a joint dialogue between government and business structures in order to create a favorable innovation and investment climate in rural areas. A promising area of further research is the practical implementation of the proposed mechanisms in the context of regional development. park.

Key words: socioeconomic development, territorial community, agri-industrial

\section{АГРАРНО-ІНДУСТРІАЛЬНІ ПАРКИ ЯК ВЕКТОР СОЦІАЛЬНО-ЕКОНОМІЧНОГО РОЗВИТКУ ТЕРИТОРІАЛЬНИХ ГРОМАД: СТАТИСТИЧНИЙ АСПЕКТ}

Ю. Ю. Мороз ${ }^{1}$, С. В. Чугаєвська ${ }^{1}$, Н. В. Чугаєвська ${ }^{2}$

Житомирський національний агроекологічний університет

бульвар Старий, 7, м. Житомир, 10008, Україна

Ягеллонський університет

вул. Голембя, 24, Краків, 31-007, Польща

Сучасний розвиток територіальних громад вимагає створення нових підходів та необхідних умов їх соціально-економічного розвитку на інноваційно-інвестиційних засадах. Реформа децентралізації 
направлена на створення додаткових фінансових ресурсів в регіонах, стимулювання до управління розвитком громади, започаткування нових господарюючих формувань на основі переходу владних повноважень на місия. Метою дослідження є обтрунтування теоретико-практичних положень, спрямованих на формування аграрно-індустріальних парків в ОТГ України, щцо сприятиме розвитку сільських територій на інновачійно-інвестищійній основі.

До кола ключових завдань віднесено: дослідження регіональних трансформацій реформи децентралізації; аналіз факторів рівня життя та трудової міграції сільського населення; розробка людино-центрованої моделі розвитку територіальних громад; аналіз напрямів покращення сочіальної та фінансової ситуаиї в громаді за результатами проведеного опитування представників депутатського корпусу місчевих громад; визначення етапів реалізачиї стратегї створення аграрноіндустріальних парків. В основу проведеного дослідження покладено наступні методи: монографічний, графічний, абстрактно-логічний, прийоми аналізу та синтезу. Авторами запропоновано механізми започаткування нового типу аграрно-промислових формувань на територіях ОТГ України - аграрно-індустріальних парків, щуо в перспективі сприятиме розвитку сільських територій на інновачійно-інвестиційній основі. Вивчення поля спільних інтересів стейкхолдерів даного прочесу підтвердило необхідність налагодження спільного діалогу між державними та бізнес-структурами задля створення сприятливого інноваційно-інвестиційного клімату в сільських регіонах. Перспективним напрямом подальших досліджень є практична реалізачія запропонованих механізмів у контексті розвитку регіонів.

Ключові слова: сочіально-економічний розвиток, територіальна громада, аграрноіндустріальний парк.

\section{Вступ}

Демократизація українського суспільства посідає пріоритетне місце серед інших реформ та передбачає продовження процесів децентралізації владних повноважень, що в перспективі надасть можливості залишати в регіонах більші фінансові ресурси і безумовно, сприятиме їх соціально-економічному розвитку. Модернізація публічної влади створює передумови задля формування клієнто-орієнтованої системи нового типу публічного управління, який стає невід'ємним елементом механізму соціальноекономічного розвитку регіонів, покращення добробуту населення, фактором підвищення його соціальної і політичної активності.

Реформа децентралізації має на меті перенесення управлінської ролі від центральних органів державної влади на місця. Зокрема, прийняття рішень про доцільність та економічну ефективність інвестиційно-інноваційних проєктів на селі, в т. ч. і заснування в ОТГ сучасної сучасних агроформувань, відтепер покладається на рішення сільської громади. Органи місцевого самоврядування згідно з Конституцією України реалізують право власника на землю від імені Українського народу i відповідно до Закону України «Про індустріальні парки» мають повноваження розпоряджатися земельними ділянками, тобто вирішують доцільність їх використання для даної спеціальної економічної зони (Pro industrialni parky..., 2012). Однак очевидним є те, що не існує єдиної моделі управління соціально-економічними проєктами. Кожному окремому регіону властиві певні особливості, потреби, наявні ресурси та умови господарювання, що $є$ визначальним в умовах впровадження децентралізації i потребує індивідуально розробленої стратегії розвитку.

Метою дослідження $\epsilon$ обгрунтування теоретико-практичних положень, спрямованих на формування аграрно-індустріальних парків в ОТГ України, що сприятиме розвитку сільських територій на інноваційно-інвестиційній основі. Зокрема, значна увага приділена вивченню спільних інтересів усіх стейкхолдерів (громадян, суб'єктів господарювання, органів місцевого самоврядування, інвесторів, представників Міжнародних організацій i Фондів, органів державного управління, громадських організацій) щодо створення сприятливого інноваційноінвестиційного клімату на територіях ОТГ України, вивченню європейського досвіду щодо функціонування індустріальних парків у країнах СС та їх влив на соціально-економічний розвиток громад.

Питанням розвитку сільських територій на інноваційно-інвестиційній засадах присвячено дослідження як українських, так і зарубіжних економістів. Більшість із них наголошує, що для успішної реалізації реформи децентралізації в 
Y. Moroz, S. Chugaievska, N. Chugaievska

Україні необхідне детальне вивчення досвіду європейських країн, а також розробка на цій основі єдиної національної концепції розвитку українських регіонів у контексті підвищення їх інноваційно-інвестиційної привабливості (Vitvitska, 2011). Інтеграція України у міжнародний економічний простір зумовлює необхідність формування інвестиційноінноваційної моделі розвитку сільського господарства (Polehenka, 2017). Порівняно 3 іншими галузями національної економіки розвиток інновацій в аграрному секторі $\epsilon$ найбільш повільним, що вимагає особливої уваги, пошуку додаткових стимулів для ефективної взаємодії усіх стейкхолдерів на ринку (Ya. Larina \& Al-Shaban Alaa Tabit Niama, 2019; O. Skydan at $a l ., 2019)$. В тісній конкурентній боротьбі за підвищення інвестиційної привабливості і створенні нових робочих місць розвинуті країни світу використовують сучасні інструменти: індустріальні парки, технопарки, вільні економічні зони, спеціальні податкові і митні преференції та бюджетні дотації. Поряд із чітко розробленою нормативно-правовою базою щодо національних індустріальних зон, бракує спеціальних методик та законодавчого базису в напрямі створення та функціонування аграрноіндустріального парку, які б враховували аналітичні аспекти для управління розвитком сільських територій, що має значну актуальність.

\section{Матеріали та методи}

Методологічною основою дослідження стали загальноекономічні засади системного вивчення процесу формування індустріальних парків України. Визначення основних проблем дослідження та шляхів їх розв'язання засновано на комплексному підході опрацювання наукових доробок вітчизняних i зарубіжних вчених, вивчення аспектів розвитку сільських територій, нормативно-правових актів та авторських розробок. Методологія проведеного дослідження базується на аналізі вітчизняної та зарубіжної літератури 3 тематики дослідження. 3 використанням вибіркового методу проведено статистичне анкетування місцевих депутатів у контексті вивчення напрямів збільшення доходів територіальних громад, розробці механізмів сприяння започаткування та розвитку підприємницької діяльності на селі. На основі даних Міжнародної асоціації наукових парків та інноваційних зон (IASP) здійснено динамічне дослідження основних тенденцій розвитку технопарків у країнах світу та, зокрема, ЄС. Прийоми аналізу i синтезу дозволили ідентифікувати проблеми соціальноекономічного розвитку сільських територій України та визначити шляхи їх вирішення. Абстрактно-логічний метод дав змогу обгрунтувати механізми реалізації стратегії створення аграрно-індустріальних парків, в основі якої мають стати законодавчі, фінансові та податкові преференції для господарюючих суб'єктів і подальшому розвитку агробізнесу.

\section{Результати досліджень та обговорення}

Реформа децентралізації передбачає відповідальність органів місцевого самоврядування перед своїми виборцями - за ефективність власної роботи та сприяння всебічному розвитку громади. В Україні процес децентралізації розпочато у 2014 році 3 прийняттям Концепції реформи місцевого самоврядування та територіальної організації влади (2014р.), Законів «Про співробітництво територіальних громад» (2014 р.), «Про добровільне об'єднання територіальних громад» (2015 р.) та змін до Бюджетного і Податкового кодексів - у контексті розподілу фінансових надходжень та статей витрат місцевих бюджетів. Цей процес дозволив сформувати, відповідно до положень Європейської хартії місцевого самоврядування, досить дієвий i спроможний інститут місцевого самоврядування на регіональному рівні - мережу об'єднаних територіальних громад (ОТГ). За даними Міністерства розвитку громад та територій України, за 6 років реформи в Україні створено 1029 ОТГ, де проживає 11,7 млн осіб населення, що становить $33,3 \%$ від загальної чисельності населення в державі (станом на початок січня 2020 р.). Загальна територія функціонуючих територіальних громад становить 246,8 млн кв. км, тобто близько 44,2 \% загальної площі України. Слід зауважити, що лідируючу позицію серед інших областей займає Житомирська область, де створено і функціонує 56 ОТГ.

Проте, великою проблемою на селі залишається стрімка трудова міграція населення, яка характеризує розвиток соціально-трудових відносин, формує ситуацію на регіональних ринках праці, регулює сфери зайнятості, рівень добробуту, структуру споживання і заощадження та процеси відтворення населення. В сучасних 
наукових працях виділяють 4 групи факторів трудової міграції населення України: економічні, політичні, соціальні та екологічні (рис. 1).

Безумовно, основними причинами, які змушують людей до пошуку роботи в інших

\section{Економічні :}

- низький рівень заробітної плати;

- невисокі стандарти життя населення;

- диспропорції економічного розвитку регіонів;

- економічна нестабільність;

- глобалізація світової економіки. регіонах чи країнах є: низька заробітна плата, високі ціни на тарифи, політична та соціальна нестабільність, відсутність постійної роботи, корупція серед органів влади, відсутність можливостей для самореалізації.

\section{Полімичні :}

- відсутність ефективних державних інструментів регулювання міграційної політики в державі;

- низький рівень демократії;

- політична нестабільність;

- високий рівень корупції;

- загроза безпеці людей.

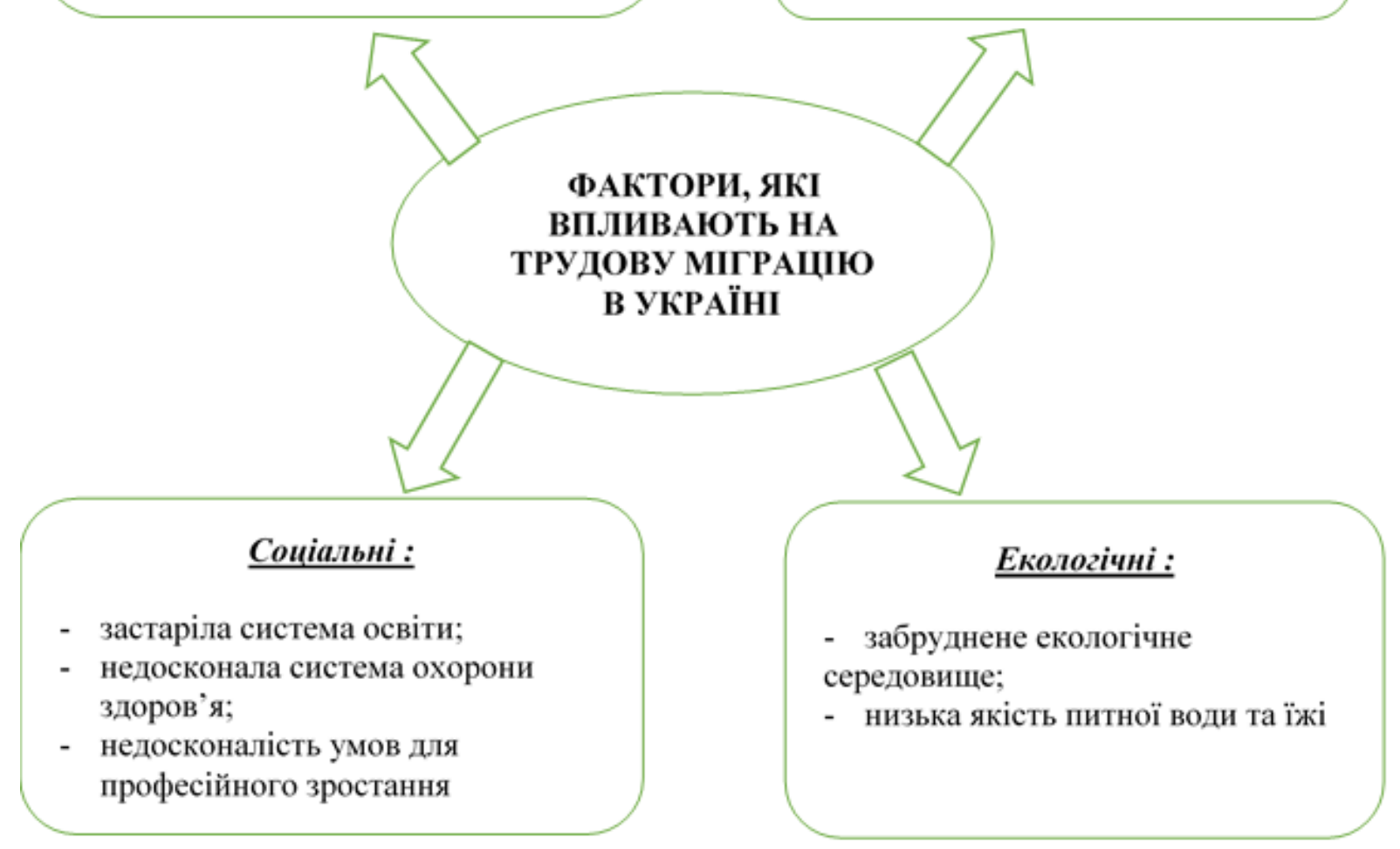

Pис. 1. Сукупність факторів, які впливають на трудову міграцію в Україні

Джерело: узагальнено та доповнено (Pitiulich, 2014; Losheniuk \& Melnyk, 2016; Pozniak, 2016; Malynovska, 2017).

Зважаючи на досвід розвинутих європейських країн, очевидно, що саме реформа децентралізації стала поштовхом для подальшого розвитку регіонів, коли радою кожної громади було розроблено стратегічний план розвитку регіону на 5-10 років, а державними актами було створено низку преференцій для їх успішного розвитку. Вважаємо, що теоретичною основою стратегії розвитку регіонів має бути людиноцентрована модель розвитку територіальних громад (рис. 2). В центрі даної моделі постає людина з їі потребами, здатністю до праці, місцем у соціумі та системою чинників самодостатності людини: забезпечення достойного рівня доходів, формування ринку землі та капіталу, якісне задоволення потреб, сімейні стосунки, забезпечення інфраструктури належного рівня, участь у процесах державного та територіального управління. 
Y. Moroz, S. Chugaievska, N. Chugaievska

\begin{tabular}{|c|c|c|}
\hline $\begin{array}{c}\text { Держсава: } \\
\text { - прийняття низки } \\
\text { нормативно-правових } \\
\text { актів задля } \\
\text { забезпечення } \\
\text { соціально- } \\
\text { економічного розвитку } \\
\text { регіонів; } \\
\text { - залучення } \\
\text { міжнародних та } \\
\text { вітчизяних } \\
\text { інвесторів; } \\
\text { - створення низки } \\
\text { податкових } \\
\text { преференцій для } \\
\text { розвитку агробізнесу }\end{array}$ & $\begin{array}{c}\text { Людино-центрована модель } \\
\text { розвитку територіальних громад в } \\
\text { контексті соціально-економічного } \\
\text { розвитку ОТГ України }\end{array}$ & $\begin{array}{c}\frac{\text { Tериторіальна }}{\text { громада: }} \\
\text { - розробка Стратегіi } \\
\text { розвитку регіону на } \\
\text { найближчі 5-10 років } \\
\text { з метою наповнення } \\
\text { державного та } \\
\text { місцевого бюджету; } \\
\text { - підтримка } \\
\text { суб'єктів місцевого } \\
\text { малого та середнього } \\
\text { агробізнесу; } \\
\text { - розширення } \\
\text { мережі об'єктів } \\
\text { соціальної } \\
\text { інфраструктури на } \\
\text { селі }\end{array}$ \\
\hline $\begin{array}{c}\text { Домогосподарства: } \\
\text { - можливість } \\
\text { покращення доходів за } \\
\text { рахунок створення } \\
\text { нових робочих місць, } \\
\text { що сприятиме в } \\
\text { перспективі } \\
\text { зменшенню міграції } \\
\text { сільського населення }\end{array}$ & & $\begin{array}{c}\text { Громадські } \\
\text { організаціӥ: } \\
\text { - налагодження } \\
\text { відкритого діалогу } \\
\text { між представниками } \\
\text { місцевого бізнесу та } \\
\text { жителями } \\
\text { територіальної } \\
\text { громади }\end{array}$ \\
\hline
\end{tabular}

Рис. 2. Людино-центрована модель розвитку територіальних громад у контексті соціально-економічного розвитку ОТГ України

Джерело: розробки авторів.

Доведено, що тільки підвищення рівня доходів кожної окремої родини сприятиме в цілому соціально-економічному розвитку громади. Вивчення джерел формування доходів членів громади дало можливість їх систематизувати та виокремити ті, які мають тенденцію до зростання в умовах реформи децентралізації влади та впровадження земельної реформи в країні. Саме такі статті доходів можуть стати найвагомішою частиною формування бюджетів громад: доходи від продажу-оренди земельних ділянок, надходження за повернення податкових платежів до регіону, де функціонують дані господарюючі суб'єкти, додаткові фінансові надходження за рахунок розвитку місцевого малого та середнього бізнесу та економічних відносин 3 іншими громадами. За результатами проведеного опитування 24 місцевих депутатів щодо розробки напрямів збільшення доходів ОТГ виявлено основні джерела покращення соціальної та фінансової ситуації в громаді (табл. 1).

Майже половина представників зазначили про необхідність повернення коштів, отриманих від місцевих суб'єктів господарювання до громади у повному обсязі (46,2 \%), на необхідності залучення додаткових інвестицій зауважили $25 \%$ ревьюерів. Найвагомішим фактором зменшення трудової міграції на селі, на думку $79,1 \%$ опитаних, є створення нових робочих місць. Для формування додаткових можливостей щодо започаткування та розвитку місцевого малого та середнього бізнесу, на думку респондентів, місцевим підприємцям потрібні доступні кредити в банках $(66,6 \%)$ та зміни у законодавстві - системі оподаткування, наданні додаткових преференцій для суб'єктів бізнес-середовища $(41,7 \%)$. 
Таблиця 1. Результати опитування місцевих депутатів щодо напрямів збільшення доходів територіальних громад, \% респондентів

\begin{tabular}{|c|c|}
\hline \multicolumn{2}{|l|}{ 1. Основні джерела збільшення наповнення бюджету громади: } \\
\hline Сплата підприємцями податків (у повному обсязі) & 16,6 \\
\hline $\begin{array}{l}\text { Повернення коштів, отриманих від місцевих суб’єктів господарювання до громади у } \\
\text { повному обсязі }\end{array}$ & 46,2 \\
\hline Перереєстрація ФОПів з міст у ОТГ & 20,8 \\
\hline Надходження коштів від туристичних послуг & 25,0 \\
\hline Надання в оренду земель комунальної власності & 20,8 \\
\hline Залучення інвесторів & 29,2 \\
\hline Виведення бізнесу з тіні & 16,7 \\
\hline \multicolumn{2}{|l|}{ 2. Заходи для зменшення трудової міграчії в громаді: } \\
\hline Політична стабільність & 25,0 \\
\hline Покращення якості життя населення (дороги, каналізація тощо) & 29,2 \\
\hline Створення нових робочих місць & 79,1 \\
\hline Соціальна захищеність населення & 33,3 \\
\hline \multicolumn{2}{|l|}{ 3. Заходи для покращення започаткування бізнесу в громаді: } \\
\hline Залучення інвесторів & 33,3 \\
\hline Доступні кредити в банках & 66,6 \\
\hline $\begin{array}{l}\text { Зміни у законодавстві (система оподаткування, надання преференцій для розвитку } \\
\text { малого та середнього бізнесу) }\end{array}$ & 41,7 \\
\hline
\end{tabular}

Джерело: власні дослідження.

Робочою гіпотезою для вирішення сформульованих вище проблем розвитку сільських територій стала розробка механізмів створення аграрно-індустріальних парків в ОТГ України, що в перспективі сприятиме залученню інвестицій, необхідних для їх розвитку, налагодженню діалогу між владою і бізнесом задля покращення рівня життя на селі. Досягнення зазначеної мети дозволить підвищити конкурентоспроможність виробленої продукції та наданих послуг у місцевості і прилеглих до неї територій, що, у свою чергу, сприятиме створенню нових робочих місць, впровадженню новітніх технологій у промисловому і аграрному виробництві, стане поштовхом для їх сталого економічному розвитку. Ідея створення аграрноіндустріальних парків як вільних економічних зон в регіонах була вперше ініційована під час фінального виступу наукової команди Житомирського національного агроекологічного університету на Всеукраїнському конкурсі студентських наукових робіт «LONG - Look of New Generation» у грудні 2019 р., де автори даного дослідження виступали науковими кураторами та експертом 3 європейського досвіду. Виконане дослідження було високо оцінене журі конкурсу, а студентська команда стала переможцем у номінації «Практична значимість та результативність».
Функціонування аграрно-індустріального парку у ОТГ дозволить збільшити надходження до бюджетів усіх рівнів, оскільки забезпечуватиме розгортання низки конкурентних промислових i сільськогосподарських виробництв, а також сприятиме підвищенню зайнятості працездатного населення. Вивчення поля інтересів стейкхолдерів процесу формування аграрно-індустріального парку в територіальних громадах України дало змогу виокремити їх спільну мету: створення сприятливого інноваційно-інвестиційного клімату регіону в контексті його соціально-економічного розвитку, залучення інвестицій, покращення добробуту населення (рис. 3).

Ключовими механізмами реалізації стратегії створення аграрно-індустріальних парків мають стати законодавчі, фінансові та податкові преференції для господарюючих суб'єктів на селі:

1. Прийняття уточнень в законопроєктах №2554a-д та №2555a-д стосовно державної підтримки індустріальних та аграрно-індустріальних парків України: наданню низьковідсоткових кредитів для сільських товаровиробників; спрощенням системи документообігу для малого бізнесу, корегування у Податковому, Трудовому та Митному кодексах стосовно діяльності аграрноіндустріального парку як суб'єкта економічної діяльності; 


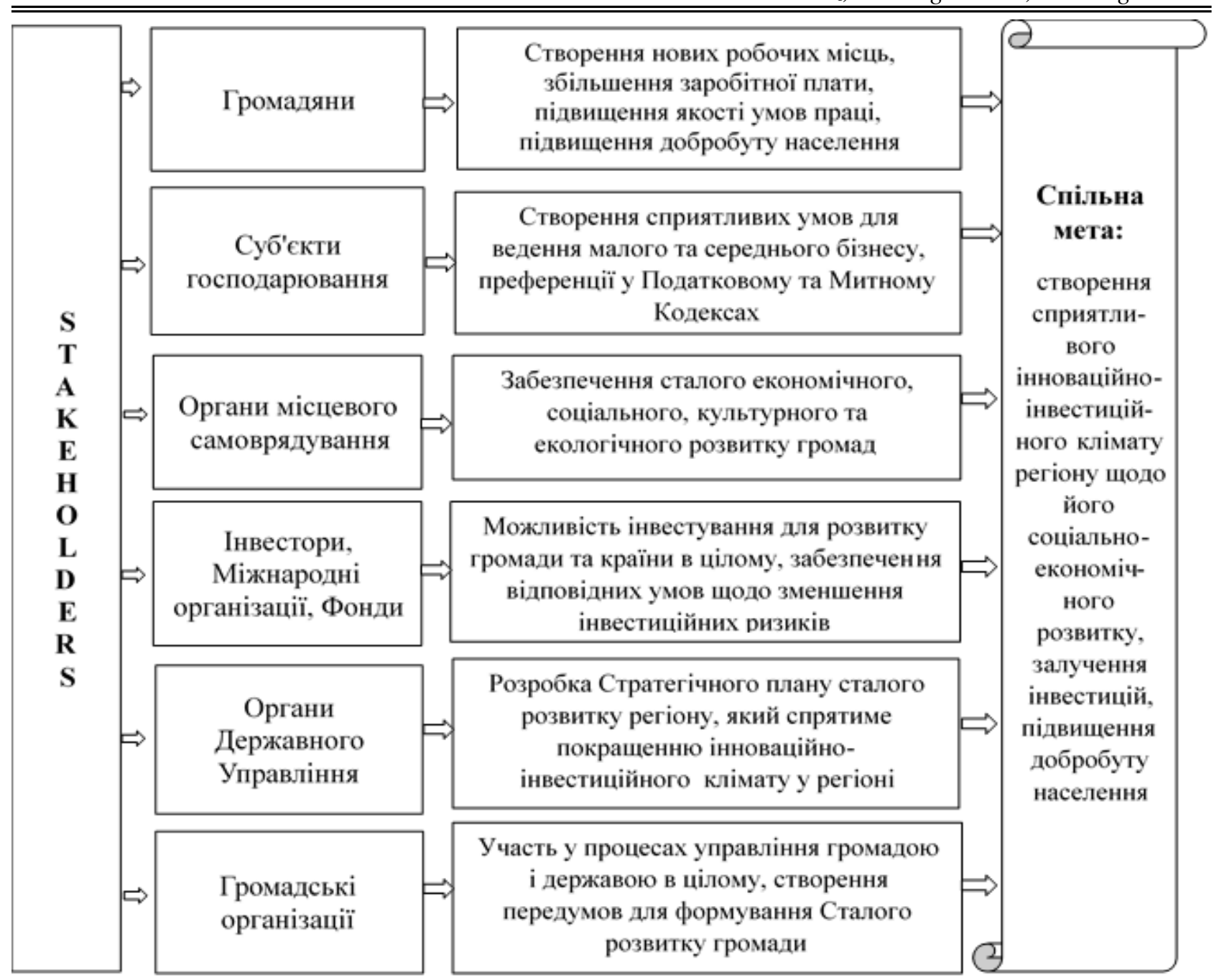

Рис. 3. Поле інтересів основних учасників (Stakeholders) процесу формування

Джерело: розробки авторів. аграрно-індустріального парку в ОТГ України

2. Преференції у Податковому кодексі стосовно сплати податків та спеціальні пільги для аграрно-індустріальних парків України: звільнення від податку на прибуток на перші п'ять років і на $50 \%$ в наступні п'ять; розстрочення сплати ПДВ на 60 днів на ввезення обладнання і устаткування; повернення $20 \%$ ПДВ аграрним товаровиробникам на утримання поголів'я ВРХ.

3. Прийняття уточнень у Митний кодекс України: звільнення від ввізного мита на аграрноіндустріальне обладнання та устаткування, молодняк ВРX, добрива, засоби обробки грунтів, посадковий матеріал, засоби для догляду за посівами тощо.

4. Уточнення у Трудовому кодексі щодо оплати праці робітників розміром не менше трьох мінімальних заробітних плат (близько 12 тис. грн) сприятиме зростанню доходів населення та зменшенню відтоку робочої сили 3 сільської місцевості.

5. Складання Стратегічного плану розвитку ОТГ стане важливим аспектом створення сприятливого інноваційно-інвестиційного клімату в регіонах на основі державної підтримки вітчизняних товаровиробників.

Для складання плану розвитку аграрноіндустріальних парків в регіонах доцільно використовувати досвід країн $\mathrm{EC}$, де реформа децентралізації проводилася паралельно із виокремленням промислових зон, інноваційних інкубаторів, технопарків та венчурних інвестиційних фондів ще у 80-90 pp. минулого століття. Наприклад, у Чехії державна програма щодо функціонування індустріальних парків була прийнята ще у 1998 р. За останні роки в цій країні створено більше сотні індустріальних парків, куди інвестори залучили більше 9 млрд Свро, що 
дало змогу створити більше 70 тис. нових робочих місць. Гарним прикладом у даному питанні є досвід Республіки Польща, де з 2002 р. дотепер сформовано 62 індустріальні парки (тоді, як в Україні лише 31), які сприяли вирішенню проблеми безробіття та залученню працівників 3 інших регіонів.

Господарюючі суб'єкти отримують низку державних пільг та преференцій: звільнення від податку на нерухомість (земельні ділянки, будівлі, споруди або їх частини, що призначені для ведення господарської діяльності); державну допомогу для впровадження нових інвестицій (інвестиції на суму понад 100 тис. євро, завершення інвестиційного проєкту протягом 48 місяців від подачі заяви); державну допомогу при купівлі компанії, яка знаходиться в стадії ліквідації та створення нових робочих місць (не менше 50 нових робочих місць у придбаній компанії протягом 12 місяців від дня подачі заявки); державну допомогу для створення нових робочих місць при реалізації нового інвестиційного проєкту (не менше 50 нових робочих місць протягом 3 років) (Pavlyuk \& Markevich, 2014).

За даними Міжнародної асоціації наукових парків та інноваційних зон, у світі зараз функціонує близько 900 технологічних парків, 3 яких близько 365 розташовані в державах-членах Свропейського Союзу. За останні 10-12 років кількість технопарків у Свропі збільшилась удвічі, головним чином завдяки прийнятій політиці Європейського Союзу, спрямованій на розвиток інновацій у державах-членах. За підрахунками IASP, в них працює близько 750 тис. працівників. Тільки у 2000-2012 рр. інвестиції в технопарки становили понад 11 млрд євро, з яких приблизно 5,6 млрд євро надійшли 3 Європейського фонду регіонального розвитку (IASP, 2012).

\section{Висновки}

Обгрунтування теоретико-практичних положень формування аграрно-індустріальних парків на територіях ОТГ України підтверджує їх сприяння розвитку територіальних громад на інноваційно-інвестиційній основі. Такі нові агроформування можуть стати своєрідною економічною зоною, яка у перспективі забезпечить:

1) створення сприятливих умов для започаткування аграрно-промислового виробництва в сільських регіонах;

2) адаптацію нових підходів до виробництва, управління виробничими процесами, впровадження новітніх технологій і ноу-хау;

3) розвиток комунальної та соціальної інфраструктури, збільшення енергетичних потужностей регіону;

4) підвищення інноваційно-інвестиційної привабливості місцевості та активізацію інвестиційних процесів;

5) започаткування нових виробництв та, відповідно, робочих місць, у тому числі із залученням висококваліфікованих працівників;

6) створення сприятливих умов щодо сприяння розвитку малого і середнього бізнесу;

7) наповненню державного та місцевого бюджетів.

Для досягнення зазначеної мети у процесі підготовки практичної концепції визначено коло ключових механізмів реалізації стратегії створення аграрно-індустріальних парків, в основу якої покладено законодавчі, фінансові та податкові преференції для господарюючих суб' єктів сільської місцевості. Вивчення спільних інтересів усіх стейкхолдерів даного процесу громадян, суб'єктів господарювання, органів місцевого самоврядування, інвесторів, представників Міжнародних організацій і Фондів, органів державного управління, громадських організацій, підтвердило їх спільну мету - створення сприятливого інноваційно-інвестиційного клімату задля соціально-економічного розвитку регіонів.

\section{References}

Davydenko, N. M. (2007). Aktyvizatsiia investytsiinoi diialnosti $\mathrm{v}$ ahrarnomu sektori ekonomiky Ukrainy [Activation of investment activity in the agricultural sector of the economy of Ukraine]. Ahroinkom, 9/10, 73-76 [in Ukrainian].

Feldmann, P. R., Jacomossi, R. R, Barrichello, A. \& Seabim Morano, R. (2019). The relationship between Innovation and Global Competitiveness: The mediating role of Management Practices evaluated by Structural Equation Modeling. $R B G N$ Revista Brasileira De Gestao De Negocios, 21 (2), 195-212. doi: 10.7819 / rbgn.v21i2.3970.

Havryliuk, M. M. (2005). Ahropromyslovomu vyrobnytstvu - innovatsiinyi shliakh rozvytku [Agroindustrial production - an innovative way of development]. Ekonomika APK, 8, 19-22 [in Ukrainian].

IASP (2012). Annual Report. Retrieved from https://issuu.com/iasp/docs/iaspannualreportprintcs5 final.

Larina, Ya. S. \& Altshaban, A. T. N. (2019). Klasyfikatsiia innovatsii $\mathrm{v}$ ahrarnomu sektori yak peredumova formuvannia marketynhovykh stratehii 
innovatsiinoho rozvytku silskohospodarskykh pidpryiemstv [Classification of innovations in the agricultural sector as a prerequisite for the formation of marketing strategies for innovative development of agricultural enterprises]. Bioekonomika ta ahrarnyi biznes, 10 (1), 58-67 [in Ukrainian].

Lelechenko, A. P., Vasilieva, O. I., Kuybida, V. S. \& Tkachuk, A. F. (2017). Mistseve samovryaduvannya $\mathrm{v}$ umovah detsentralizatsiyi povnovazhen [Local government in terms of decentralization of powers]. Kyiv [in Ukrainian].

Malinyak, B. S. (2020). Byudzhetne planuvannya i prioriteti rozvitku gromad: instrumenty garmonizatsiyi ta problemi yih zastosuvannya. [Budget planning and priorities for community development: tools for harmonization and problems of their application]. Finansy Ukrayiny, 3, 94-111. doi: https://doi.org/10.33763/finukr2020.03.094 [in Ukrainian].

Malynovska, O. A. (2017). Bezpeka ta nebezpeka podviinoho hromadianstva. [Security and danger of dual citizenship]. Stratehichni prioritety, 3, 29-35 [in Ukrainian].

Melnyk, T. M. \& Losheniuk, O. V. (2016). Vplyv mizhnarodnoi trudovoi mihratsii na ekonomiku Ukrainy [The impact of international labor migration on the economy of Ukraine]. Biznes Inform, 12, 29-35 [in Ukrainian].

Mind (2018). Industrialni parki v Ukrayini: scho tse take i chi vdastsya yih reanimuvaty [Industrial parks in Ukraine: what is it and whether it will be possible to revive them]. Retrieved from https://mind.ua/publications/20186816-industrialniparki-v-ukrayini-shcho-ce-take-i-chi-vdastsya-yihreanimuvati [in Ukrainian].

Ministerstvo rozvytku hromad ta terytorii Ukrainy (2020). Monitoring protsesu detsentralizatsiyi vlady ta reformuvannya mistsevogo samovryaduvannya stanom na 10 sichnya $2020 \mathrm{r}$. [Monitoring of the process of decentralization of power and reform of local self-government as of January 10, 2020]. Retrieved from https://decentralization.gov.ua/uploads/library/file/5 26/10.01.2020.pdf. [in Ukrainian].

Pavlyuk, A. P. \& Markevich, K. L. (2014). Zakordonniy dosvid stimulyuvannya rozvitku industrialnih parkiv: visnovki dlya Ukrayini [Foreign experience in stimulating the development of industrial parks: conclusions for Ukraine]. Aktualni problemi mizhnarodnih vidnosin, 122 (I), 138-147 [in Ukrainian].

Pitiulich, M. I. (2014). Novitni tendentsii rozvytku mizhnarodnoi trudovoi mihratsii ta yikh naslidky dlia Ukrainy [The latest trends in international labor migration and their consequences for Ukraine]. Naukovyi visnyk Mukachivskoho derzhavnoho universytetu Ser. Economica, 1, 96-100 [in Ukrainian].

Polehenka, M. A. (2017). Osoblyvosti innovatsiinoi diialnosti $\mathrm{v}$ ahropromyslovykh pidpryiemstvakh Ukrainy [Features of innovative activity in agro-industrial enterprises of Ukraine]. Ahrosvit, 6, 49-54 [in Ukrainian].

Pozniak, O. V. (2016). Otsiniuvannia naslidkiv zovnishnoi trudovoi mihratsii v Ukraini [Assessment of the consequences of external labor migration in Ukraine]. Demographiia ta sotsialna economika, 2 (27), 169-182 [in Ukrainian].

Pro dobrovilne obiednannia terytorialnykh hromad [About voluntary association of territorial communities]. № 157-VIII. (2015). [in Ukrainian].

Pro industrialni parky [About industrial parks]. № 5018-VI. (2012). [in Ukrainian].

Pro spivrobitnytstvo terytorialnykh hromad [About cooperation of territorial communities]. № 1508-VII. (2014). [in Ukrainian].

Prysiazhniuk, O., Plotnikova, M. \& Buluy, O. (2018). Cluster approach in administration of rural areas. Management Theory and Studies for Rural Business and Infrastructure Development, 40 (2), 243-253. http://doi.org/10.15544/mts.2018.2322.

Skydan, O. V., Shvets, T. V., Plotnikova, M. F. \& Kostyuk, L. P. (2019). Perspektyvni modeli rozvytku pidpryiemnytstva ta publichnoho upravlinnia terytorialnykh hromad [Perspective models of business development and public administration of territorial communities]. Scientific horizons, 9 (82), 3-12. doi: 10.33249/2663-21442019-82-9-3-12 [in Ukrainian].

Tarasovych, L. V \& Yakymchuk, D. O. (2019). Stratehichne marketynhove upravlinnia rozvytkom silskykh terytorii [Strategic marketing management of rural development]. Scientific horizons, 12 (85), 15-23. doi: 10.33249/2663-2144-2019-85-12-15-23 [in Ukrainian].

Vytvytska, O. D. (2011). Formuvannia stratehii innovatsiinoho rozvytku ahrarnykh pidpryiemstv [Formation of strategy of innovative development of agricultural enterprises]. Economika APK, 10, 132138 [in Ukrainian].

Yushko, S. V. (2018). Rol mistsevykh podatkiv i zboriv u formuvanni dokhodiv biudzhetiv mistsevoho samovriaduvannia [The role of local taxes and fees in the formation of revenues of local government budgets]. Finansy Ukrainy, 1, 72-87.doi: https://doi.org/10.33763/finukr2018.01.072 [in Ukrainian]. 